American Journal of Animal and Veterinary Sciences 5 (4): 274-281, 2010

ISSN 1557-4555

(C) 2010 Science Publications

\title{
Effects of Vitamin A on Growth Performance, Antioxidant Status and Blood Constituents in Lactating Grey Goat
}

\author{
Weiren Yang, Ping Wang, Yuanqiang Jing, Zaibin Yang, \\ Chongyu Zhang, Shuzhen Jiang and Guiguo Zhang \\ Department of Animal Science and Technology, Shandong Agricultural University, \\ Taian, Shandong, PR China, 271018
}

\begin{abstract}
Problem statement: It is regarded that vitamin A protects cells from damage by radicals which are believed to contribute to certain chronic diseases and regulates immune function of animals by protection of mucosal epithelium acting as the first defense barrier. All these properties of vitamin A may be attributable to its antioxidant activity. This study was to evaluate the effects of different levels of vitamin A on growth performance, antioxidant status and blood constituents of lactating ewes. Approach: Thirty-two multiparous lactating ewes of Grey goat $(\mathrm{BW}=35.1 \pm 1.1 \mathrm{~kg}$ ) were divided into four groups of eight with four different supplementing levels of vitamin A (0, 2000, 3000 and 5000 $\left.\mathrm{IU} \mathrm{kg}{ }^{-1} \mathrm{DM}\right)$. Ewes were fed in individual lot at ad libitum intake and had free access to water. Average daily feed intake and average milk yield of ewes were measured weekly. Blood was obtained every 14 days to evaluate activities of antioxidant enzymes, blood constituents and vitamin A levels in serum. Results: In general, feed intake, milk yield and feed efficiency were not affected by vitamin A supplementation. However, supplementation of vitamin A increased $(p<0.05)$ activities of glutathione peroxidase and total antioxidant capacity, but reduced $(p<0.05)$ concentrations of malondialdehyde in serum of ewes. Red cells number increased linearly $(p<0.01)$ and quadraticly $(p<0.01)$ with incremental amount of vitamin A. Number of lymphocyte, concentration of hemoglobin and haematocrit were increased $(\mathrm{p}<0.05)$ by supplementing vitamin A. Serum retinol concentration was higher $(\mathrm{p}<0.05)$ for ewes supplemented with vitamin A at $5000 \mathrm{IU} \mathrm{kg}^{-1}$ than for control ewes, but retinol concentration in milk was not difference $(\mathrm{p}>0.05)$ among treatments. Conclusion/Recommendations: Addition of vitamin A improved antioxidant status of lactating Grey goat thereby enhanced their immune function. The optimum level of vitamin A supplementation for this purpose was between 2000 and $3000 \mathrm{IU} \mathrm{kg}^{-1} \mathrm{DM}$.
\end{abstract}

Key words: Lactating ewe, growth performance, antioxidant status, blood metabolites, High Performance Liquid Chromatography (HPLC), Total Superoxide Dismutase (T-SOD), Optical Density (OD), Malondialdehyde (MDA), ANOVA, immune function, hemoglobin, lymphocyte, glutathione peroxidase

\section{INTRODUCTION}

Essential functions of vitamin A in vision, growth, epithelial cell differentiation, bone development and reproduction have been well established (Bridges, 1984; Dennert, 1984; Roberts and Sporn, 1984; Wald, 1968). It has also been suggested that vitamin A protects cells from damage by radicals which are believed to contribute to certain chronic diseases and play a role in the degenerative processes (Kamiloglu et al., 2005). It is regarded that vitamin A regulates immune function of animals by protection of mucosal epithelium acting as the first defense barrier (Brody, 1993) and by supporting the differentiation of epithelial cells. All these properties of vitamin A may be attributable to its antioxidant activity. Research is needed to confirm this. Comparing to monogastric animals, ruminant especially grazing ruminant get more vitamin A from their diet. Vitamin A is generally supplemented to ruminant especially to those confined to insure their optimum health and maximum productivity (Alosilla et al., 2007). However, it has been reported that as much as $80 \%$ of the vitamin A supplemented were degraded in the rumen after ingestion and the ruminal degradation of vitamin A was in a diet dependent manner, being higher for concentrate than for forage diet (Rode et al., 1990; Alosilla et al., 2007). Vitamin A, because of its essential role in metabolism of epithelial tissues,

Corresponding Author: W.R. Yang, Department of Animal Science and Technology, Shandong Agricultural University, Taian, Shandong, PR China, 271018 
might be required in greater amounts by lactating (Swanson et al., 1986). In early lactation, the ewe's nutrient requirements increase dramatically, particularly for ewes nursing twin or triplet lambs (Pope et al., 1949). Supplementation of carotene to ruminant during lactation was essential for normal vitamin A nutrition regardless of whether the animals had low or high liver vitamin A stores at parturition (Meacham et al., 1970). Requirements of vitamin A of animal have been recommended for various productivities (e.g., NRC). However, the adequate level of dietary vitamin A for maximal antioxidant activity and immune-enhancing of lactating ewe need to be further evaluated. The objective of present study was to assess the effects of different levels of vitamin A on growth performance, antioxidant status and blood constituents in lactating ewes of Grey goat.

\section{MATERIALS AND METHODS}

Animals in this study were cared according to the experimental protocol that was reviewed and approved by Animal Nutrition Research Institute of Shandong Agricultural University.

Treatment of animals: Thirty-two multiparous lactating ewes of Grey goat $(35.1 \pm 1.1 \mathrm{~kg}$ initial BW) were randomly allocated to four dietary treatments of eight per treatment on the basis of days of lactation. The four groups (treatments) of ewes were fed a basal diet with supplementation of vitamin $\mathrm{A}$ at the levels of 0 (Control), 2000, 3000 or $5000 \mathrm{IU} \mathrm{kg}^{-1}$. The basal diet (Table 1) was formulated to meet nutrient requirement of goat (Feeding Standard of Goat of the People's Republic of China; NY/T 816-2004). Vitamin A, which was obtained from Zhejiang Xinchang Pharmaceutical (China) as a powder $\left(10^{5} \mathrm{IU}\right.$ retinol $\left.\mathrm{g}^{-1}\right)$, was supplemented daily as premixes that were mixed with other ingredients every two weeks and stored in covered containers prior to use. Dry Spanish potato vine was the only forage source and the grain sources contained either very low or undetectable carotene. Therefore, the diets were assumed no carotenes derived vitamin A (Arnett et al., 2007).

The ewes were fed individually in dry lots, once daily, at ad libitum feed intake and had free access to water throughout the entire experimental period. Ewes were milked twice daily at 07:00 and 17:00 before feeding. Orts were also collected and weighed weekly to determine the feed intake and feed efficiency.

Collection of samples: Blood samples were taken at the beginning of the experiment and then fortnightly before morning feeding from each ewe via jugular venipuncture into 5 - $\mathrm{mL}$ red-topped (non-heparinized) and $2 \mathrm{~mL}$ purple-topped (containing anticoagulant) vacuum tubes. The blood samples in 5-mL red-topped were incubated at $37^{\circ} \mathrm{C}$ for $2 \mathrm{~h}$, subsequently centrifuged at 2, $500 \times \mathrm{g}$ for $10 \mathrm{~min}$ and the serum was stored at $-20^{\circ} \mathrm{C}$ for analyses of anti-oxidant enzymes and metabolites as described in 2.3 and 2.4. The blood samples in $2 \mathrm{~mL}$ purple-topped were used for routine analysis of blood cells and metabolites immediately after collection as described in 2.5. Milk was collected for vitamin A determination as described in 2.3.

\section{Determination of vitamin $A$ in serum and milk:} Serum and milk retinol concentration was analyzed by High Performance Liquid Chromatography (HPLC) according to the methods described by Barua and Olson (1998). Retinyl acetate was obtained from Department of Animal Husbandry and Veterinary bureau of Shandong Province (China) and used as the internal standard. Because retinol constituted nearly $85 \%$ of the detected retinoids in our samples, vitamin A content was interpreted as the total of retinol esters present in each sample (Barua and Olson, 1998). Serum lipids were extracted twice with 4 volumes hexane, dried under a nitrogen gas stream and re-dissolved in methanol (Bieri et al., 1979). The samples were processed under yellow light to minimize the deterioration of retinol. The mobile phase of HPLC contained $2 \%$ methanol with the flow rate of $1.0 \mathrm{~mL}$ $\min ^{-1}$. Retinoids were separated on a $\mathrm{C}-18$ reversed phase column, with $10 \mathrm{mM}$ ammonium acetate in $12.5 \%$ aqueous methanol as solvent. Absorbance at 340 nm was used to quantify retinoids (Smith et al., 1987).

Table 1: Composition of (\%) the basical diets ${ }^{\mathrm{a}}$

\begin{tabular}{|c|c|}
\hline Ingredients & Amount $(\%)$ \\
\hline 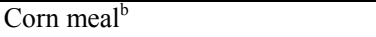 & 18.30 \\
\hline Wheat bran & 5.00 \\
\hline Soybean meal & 15.00 \\
\hline Dry spanish potato vine powder ${ }^{\mathrm{c}}$ & 60.00 \\
\hline Dicalcium phosphate & 1.00 \\
\hline Limestone & 0.50 \\
\hline Premix $^{\mathrm{d}}$ & 0.50 \\
\hline Total & 100.00 \\
\hline \multicolumn{2}{|l|}{ Nutrient level } \\
\hline $\mathrm{ME}\left(\mathrm{MJ} \mathrm{kg}^{-1}\right)$ & 10.62 \\
\hline $\mathrm{CP}(\%)$ & 12.61 \\
\hline \multicolumn{2}{|c|}{$\begin{array}{l}\text { a: Control group was fed the basal diet. The other treatment diets were } \\
\text { the same basal diet supplemented with vitamin A at the level of } 500 \text {, } \\
1000 \text { and } 2000 \mathrm{IU} \mathrm{kg} \mathrm{kg}^{-1} \text {, } \text { : Grounded to the particle of } 425 \mu \mathrm{m} \text {; } \\
{ }^{\mathrm{c}} \text { :Grounded to the particle of } 3350 \mu \mathrm{m} \text {; d: Premix provided per } \\
\text { kilogram of complete diet: S } 200 \mathrm{mg}, \mathrm{Fe} 24 \mathrm{mg}, \mathrm{Cu} 8 \mathrm{mg} \text {, Mn } 40 \mathrm{mg} \text {, } \\
\mathrm{Zn} 40 \mathrm{mg} \text {, I } 0.3 \mathrm{mg} \text {, Se } 0.2 \mathrm{mg} \text {, Co } 0.1 \mathrm{mg} \text {, Vitamin D } 2,000 \mathrm{IU} \text {, } \\
\text { Vitamin E } 20 \mathrm{IU} \text {, Calcium pantothenate } 30 \mathrm{mg} \text {, Niacin } 25.6 \mathrm{mg}\end{array}$} \\
\hline
\end{tabular}


Assay of antioxidant enzymes in serum: Total Superoxide Dismutase (T-SOD) activity was determined with a T-SOD Assay Kit A001 (Institute of Biological Engineering of Nanjing Jianchen, Nanjing, China). Superoxide was generated in xanthing oxidase and hypoxanthine and the superoxide scavenging effect of serum was determined according to the method described by Oyanagui (1984). The activity of SOD is expressed as units per $\mathrm{mL}$ of serum and determined by using a colorimetric method measuring the Optical Density (OD) at $550 \mathrm{~nm}$ with a spectrophotometer (UV2000, UNICO Instruments Co., Ltd, Shanhai, China). One unit of enzyme activity was defined as the amount of the enzyme that inhibited the rate of nitrite production by $50 \%$ at $37^{\circ} \mathrm{C}$.

Glutathione peroxidase (GSH-Px) activity was determined with a GSH-Px Assay Kit A005 (Institute of Biological Engineering of Nanjing Jianchen, Nanjing, China) using the method described by Hafemen (1974). The GSH-Px decomposes hydrogen peroxide $\left(\mathrm{H}_{2} \mathrm{O}_{2}\right)$ and other organic hydroperoxides and therefore glutathionewas used as substrate in the assay. Activity of GSH-Px was detected with 5, 5'-dithiobis- $\rho$ nitrobenzoic acid by measuring the OD of the reaction solution at $412 \mathrm{~nm}$. One unit of GSH-Px activity was defined as the amount of enzyme per $0.1 \mathrm{~mL}$ of serum that would catalyze the conversion of $1 \mu \mathrm{mol} \mathrm{L}{ }^{-1}$ of $\mathrm{GSH}$ to oxidized $\mathrm{GSH}$ at $37^{\circ} \mathrm{C}$ in $5 \mathrm{~min}$ (Zhang et al., 2009).

The concentration of Malondialdehyde (MDA) was determined with a MDA Assay Kit A003 (Institute of Biological Engineering of Nanjing Jianchen, Nanjing, China). It was analyzed using thiobarbituric acid method by measuring spectrophotometrically malondialdehyde reactive products at OD $532 \mathrm{~nm}$ as described by Placer et al. (1966).

Serum samples were analyzed for Total Antioxidant Capacity (T-AOC) with a T-AOC Assay Kit A015 (Institute of Biological Engineering of Nanjing Jianchen, Nanjing, China) using the method of ferric reducingantioxidant power assay (Benzie and Strain, 1996).

Analysis of blood routine and metabolites: The assay included measuring white cells, red cells, lymphocyte, intermediate cell, granulocyte, hemoglobin, haematocrit, mean corpuscular hemoglobin and mean corpuscular hemoglobin concentration. Blood cells were determined using an aperture-impedance method (Dallak, 2009) by an automatic blood cell analyzer (PE6800 Vet, Electronica Co., Ltd. Shenzhen Pukang, China). When a diluted sample including blood cell is injected into the aperture, the change of electrical resistance due to the passing blood cells can be estimated approximately. Since a constant voltage is supplied across the aperture, the electrical resistance causes a pulse having a magnitude proportional to the cell size. The total number of electrical pulses corresponds to the number of blood cells. The blood cells are distinguished by the difference of pulse height because of their different volumes (Satake et al., 2002).

Statistical analyses: Average feed intake was calculated as the summary of the difference of diet offered and orts of each week dividing by the total number of the experiment day and average daily milk yield was calculated by the total number of the experiment day. Feed efficiency was computed as feed:milk.

All data were statistically analyzed as completely randomized designs by one-way ANOVA using GLM model of SAS (2000) with vitamin A level as main effect and individual animal as statistical unit. For analysis of blood cells, metabolites and enzyme activity, the data obtained from the first sampling (at the beginning of the experiment) was used as a covariate and the mean values of the other 4 time samples of each ewe was used. Duncan's multiple range test was used to determine significant differences between treatment means. The efficacy of supplemental vitamin A was determined by using a contrast between control and additives. Difference was declared at $\mathrm{p}<0.05$.

\section{RESULTS}

Growth performance: All ewes irrespective of treatments had similar feed intake, milk yield and feed efficiency (Table 2). The mean average daily gain, average daily milk yield and feed efficiency were 1.38 $\mathrm{kg}, 1.26 \mathrm{~kg}$ and 1.11 over the entire experimental period respectively.

Table 2: Feed intake, milk yield and feed efficiency of ewes fed diets with or without vitamin A supplementation

\begin{tabular}{|c|c|c|c|c|c|c|c|c|}
\hline \multirow[b]{2}{*}{ Item } & \multicolumn{4}{|c|}{ Levels of vitamin $\mathrm{A}, \mathrm{IU} \mathrm{kg}^{-1}$} & \multirow[b]{2}{*}{$\mathrm{SEM}^{\mathrm{a}}$} & \multirow{2}{*}{$\begin{array}{l}\text { Control Vs. } \\
\text { vitamin } A^{\text {b }}\end{array}$} & \multicolumn{2}{|c|}{ Vitamin A effect (P-value) } \\
\hline & 0 & 2000 & 3000 & 5000 & & & Linear & Quadratic \\
\hline Average Feed Intake $\left(\mathrm{kg} \mathrm{day}^{-1}\right)$ & 1.37 & 1.40 & 1.39 & 1.36 & 0.017 & 0.359 & 0.866 & 0.242 \\
\hline Average Milk yield $\left(\mathrm{kg} \mathrm{day}^{-1}\right)$ & 1.26 & 1.42 & 1.22 & 1.21 & 0.070 & 0.78 & 0.300 & 0.309 \\
\hline Feed: Milk $\left(\mathrm{kg} \mathrm{k}^{-1} \mathrm{~g}\right)$ & 1.10 & 0.99 & 1.14 & 1.22 & 0.083 & 0.883 & 0.189 & 0.224 \\
\hline
\end{tabular}

${ }^{a}$ : SEM = Standard Error of the Mean; ${ }^{b}$ : Control Vs. vitamin A means contrast of the control treatment versus all vitamin A treatments 
American J. Animal \& Vet. Sci., 5 (4): 274-281, 2010

Table 3: Serum and milk retinol concentration of ewes of Grey goat fed diets with or without vitamin A supplementation.

\begin{tabular}{|c|c|c|c|c|c|c|c|c|}
\hline \multirow[b]{2}{*}{ Retinol concentration, IU mL $\mathrm{m}^{-1}$} & \multicolumn{4}{|c|}{ Levels of vitamin A, IU kg-1 } & \multirow[b]{2}{*}{$\mathrm{SEM}^{\mathrm{c}}$} & \multirow{2}{*}{ 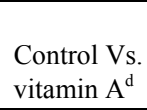 } & \multicolumn{2}{|c|}{ Vitamin A effect (P-value) } \\
\hline & 0 & 2000 & 3000 & 5000 & & & Linear & Quadratic \\
\hline Retinol in milk & 0.67 & 0.84 & 0.73 & 1.01 & 0.137 & 0.233 & 0.135 & 0.305 \\
\hline Retinol in blood & $0.66^{\mathrm{b}}$ & $0.75^{\mathrm{ab}}$ & $0.81^{\mathrm{ab}}$ & $0.93^{\mathrm{a}}$ & 0.068 & 0.046 & 0.007 & 0.026 \\
\hline
\end{tabular}

Table 4: Antioxidant enzymatic activity in the serum of ewes of Grey goat fed diets with or without vitamin A supplementation.

\begin{tabular}{|c|c|c|c|c|c|c|c|c|}
\hline \multirow[b]{2}{*}{ Item } & \multicolumn{4}{|c|}{ Levels of vitamin $\mathrm{A}, \mathrm{IU} \mathrm{kg}^{-1}$} & \multirow[b]{2}{*}{$\mathrm{SEM}^{\mathrm{c}}$} & \multirow{2}{*}{$\begin{array}{l}\text { Control Vs. } \\
\text { vitamin } A^{d}\end{array}$} & \multicolumn{2}{|c|}{ Vitamin A effect (P-value) } \\
\hline & 0 & 2000 & 3000 & 5000 & & & Linear & Quadratic \\
\hline Glutathione peroxidase $\left(\mathrm{U} \mathrm{mL}^{-1}\right)$ & $164.61^{\mathrm{b}}$ & $215.46^{\mathrm{a}}$ & $207.04^{\mathrm{a}}$ & $192.40^{\mathrm{ab}}$ & 10.634 & 0.002 & 0.115 & 0.004 \\
\hline Superoxide dismutase $\left(\mathrm{U} \mathrm{mL}^{-1}\right)$ & 180.82 & 185.52 & 192.69 & 196.51 & 6.460 & 0.153 & 0.067 & 0.189 \\
\hline Malondialdehyde $\left(\mathrm{nmol} \mathrm{mL}^{-1}\right)$ & $4.88^{\mathrm{a}}$ & $4.56^{\mathrm{a}}$ & $3.66^{\mathrm{b}}$ & $4.43^{\mathrm{ab}}$ & 0.301 & 0.070 & 0.170 & 0.087 \\
\hline Total antioxidant capacity $\left(\mathrm{U} \mathrm{mL}^{-1}\right)$ & $3.34^{\mathrm{b}}$ & $4.10^{\mathrm{a}}$ & $4.00^{\mathrm{a}}$ & $3.50^{\mathrm{ab}}$ & 0.209 & 0.035 & 0.646 & 0.012 \\
\hline
\end{tabular}

${ }^{\mathrm{a}, \mathrm{b}}$ : Means within a row containing different superscripts tended to differ $(\mathrm{p}<0.05) ;{ }^{\mathrm{c}}$ : $\mathrm{SEM}=$ Standard Error of the Mean; ${ }^{\mathrm{d}}$ :Control Vs. vitamin A means contrast of the control treatment versus all vitamin A treatments

Table 5: Blood constituents of ewes of Grey goat fed diets with or without vitamin A supplementation.

\begin{tabular}{|c|c|c|c|c|c|c|c|c|}
\hline \multirow[t]{2}{*}{ Item } & \multicolumn{4}{|c|}{ Levels of vitamin $\mathrm{A}, \mathrm{IU} \mathrm{kg}^{-1}$} & \multirow[b]{2}{*}{$\mathrm{SEM}^{\mathrm{c}}$} & \multirow{2}{*}{$\begin{array}{l}\text { Control Vs. } \\
\text { vitamin } \mathrm{A}^{\mathrm{d}}\end{array}$} & \multicolumn{2}{|c|}{ Vitamin A effect (P-value) } \\
\hline & 0 & 2000 & 3000 & 5000 & & & Linear & Quadratic \\
\hline White blood cell $\left(10^{9} \mathrm{~L}^{-1}\right)$ & 17.06 & 18.22 & 16.84 & 17.91 & 1.722 & 0.760 & 0.845 & 0.979 \\
\hline Lymphocyte $\left(10^{9} \mathrm{~L}^{-1}\right)$ & $4.83^{\mathrm{b}}$ & $7.08^{\mathrm{a}}$ & $7.11^{\mathrm{a}}$ & $5.65^{\mathrm{ab}}$ & 0.673 & 0.032 & 0.744 & 0.030 \\
\hline Intermediate cell $\left(10^{9} \mathrm{~L}^{-1}\right)$ & 2.37 & 2.68 & 2.78 & 2.14 & 0.320 & 0.663 & 0.499 & 0.289 \\
\hline Granulocyte $\left(10^{9} \mathrm{~L}^{-1}\right)$ & 10.75 & 12.13 & 11.80 & 10.18 & 0.998 & 0.593 & 0.493 & 0.318 \\
\hline Red blood cell $\left(10^{12} \mathrm{~L}^{-1}\right)$ & $1.46^{\mathrm{b}}$ & $1.70^{\mathrm{a}}$ & $1.81^{\mathrm{a}}$ & $1.79^{\mathrm{a}}$ & 0.062 & 0.000 & 0.003 & 0.000 \\
\hline Hemoglobin $\left(\mathrm{g} \mathrm{L}^{-1}\right)$ & $64.73^{\mathrm{b}}$ & $65.15^{\mathrm{b}}$ & $72.78^{\mathrm{a}}$ & $64.70^{\mathrm{b}}$ & 1.631 & 0.225 & 0.787 & 0.020 \\
\hline Haematocrit (\%) & $5.03^{\mathrm{b}}$ & $5.69^{\mathrm{b}}$ & $6.44^{\mathrm{a}}$ & $5.65^{\mathrm{b}}$ & 0.258 & 0.008 & 0.166 & 0.003 \\
\hline Mean corpuscular volume (fL) & 34.00 & 34.05 & 34.36 & 34.04 & 0.145 & 0.383 & 0.756 & 0.284 \\
\hline Mean corpuscular hemoglobin (pg) & 42.53 & 41.14 & 39.28 & 39.63 & 1.804 & 0.227 & 0.238 & 0.374 \\
\hline $\begin{array}{l}\text { Mean corpuscular hemoglobin } \\
\text { concentration }\left(\mathrm{g} \mathrm{L}^{-1}\right)\end{array}$ & 1232.18 & 1224.46 & 1156.98 & 1177.39 & 62.207 & 0.518 & 0.453 & 0.679 \\
\hline
\end{tabular}

Retinol concentration in blood and milk: Retinol concentration in blood and milk was showed in Table 3. Supplementation of vitamin A at the level up to $5000 \mathrm{IU}$ $\mathrm{kg}^{-1}$ DM increased retinol concentration in the serum $(\mathrm{L}, \mathrm{p}<0.01 ; \mathrm{Q}, \mathrm{p}<0.05)$ and ewes supplemented with vitamin $\mathrm{A}$ at the level of $5000 \mathrm{IU} \mathrm{kg}^{-1}$ had higher serum concentration of retinol than control ewes. The retinol concentration in milk was not difference among treatments $(\mathrm{p}>0.05)$.

Serum antioxidant status: Results of antioxidant indicates in serum are showed in Table 4. Regardless of the supplementation rate, vitamin A increased $(\mathrm{p}<0.05)$ activities of GSH-Px and T-AOC, but reduced $(\mathrm{p}<0.05)$ MDA content in the serum over the entire experimental period. The activities of GSH-Px $(\mathrm{p}<0.01)$ and T-AOC $(p<0.05)$ exhibited a quadratically increase as the proportion of vitamin A in the diet increased. Supplemented vitamin A from 2000-3000 IU kg-1 significantly increased $(p<0.05)$ the activities of GSH-
Px and T-AOC in serum. Content of MDA in serum had a prominent decline $(\mathrm{p}<0.05)$ by $3000 \mathrm{IU} \mathrm{kg}^{-1}$ vitamin A supplementation. Increasing supplementation of vitamin A tended to be linearly $(p=0.067)$ increased the activity of T-SOD in serum, but was not significantly for it in this condition.

Changes of blood routine and metabolites: Effect of vitamin A supplementation on blood routine and metabolites is shown in Table 5. Red blood cells showed both linear $(p<0.01)$ and quadratic $(p<0.01)$ increases in response to the dietary additions of vitamin A. $3000 \mathrm{IU} \mathrm{kg}$ vitamin A supplementation had greater $(p<0.05)$ lymphocyte, hemoglobin and haematocrit than the control group and other test groups. Red blood cells were significantly increased $(p<0.05)$ by the test groups. Supplemented with vitamin A did not change other blood parameters over the experimental period or among the experimental groups $(\mathrm{p}>0.05)$. 


\section{DISCUSSION}

Effect of vitamin A on growth performance of ewes: Vitamin A is routinely supplemented to ruminant diets to insure maximum health and productivity (Alosilla $e t$ al., 2007). In this experiment, feed intake, milk yield and feed efficiency were not affected by vitamin A supplemented at the level of 2000,3000 or $5000 \mathrm{IU}$ $\mathrm{kg}^{-1}$ DM. The results are in agreement with previous studies (Colby et al., 1950; Swanson et al., 1968) that vitamin A supplementation did not enhance lactation in milk production ewes and cows. Swanson et al. (1968) reported that vitamin A supplementation started either prepartum or in midlactation failed to change cow milk yields significantly. May et al. (1987) and Oka et al. (1998) demonstrated that no linear or quadratic effects of vitamin A levels on live weight gain, feed intake, or feed efficiency when goat fed high or low vitamin A diets. These experiments confirmed reports by Myers et al. (1959) that vitamin A had no lactation stimulating effect in dairy ruminant. On the contrary, Krauss (1939) demonstrated that vitamin A or carotene seemed to improve lactation of dairy cattle. Therefore, the discrepancy between this study and others indicated firstly that even though the vitamin A contributed by corn and soybean meal is assumed to be of low bioavailability, it may still meet the nutritional demands of the animal for normal growth and secondly that the levels of vitamin A used in this study might not be sufficient to promote lactating ewe performance.

Effect of vitamin $A$ on serum and milk retinol concentration of ewes: Liver is the primary storage site for vitamin A and serum level of retinol was used as an indicator of vitamin A status in the liver (Oka et al., 1998; Carrillo-Lopez et al., 2010; Myers et al., 1959). It is regarded that vitamin $\mathrm{A}$ intake is necessary to maintain the optimal level of vitamin A in blood (May et al., 1987). This study showed that supplementation of vitamin $\mathrm{A}$ at the level of 1000-5000 IU kg${ }^{-1} \mathrm{DM}$ linearly increased the retinol concentration in the serum of lactating ewe. The results are in agreement with previous studies (Chew, 1996; Alosilla, 2007; Arana et al., 2008) that reported dietary supplementation of vitamin A increased retinol level in the serum of lambs and cattle. This information indicated that as the supplementation level increasing greater amount of vitamin A escaped the ruminal degradation and absorbed in the small intestine to exert its antioxidant effect on animal physiology.

Swanson et al. (1968) indicated that retinol level of milk was not an important factor in determining vitamin A utilization, as measured by loss of liver stores. Our study found that vitamin A supplementation had no effect on the milk retinol concentration of lactating ewes. Ray (1948) reported that there was practically no difference in the carotene and vitamin A contents of milk from the cows and goats. Little is known about the vitamin A requirement for milk production but it would seem quite safe to assume that an intake which allows normal reproduction should permit normal lactation. The degree of concentration of the vitamin A in milk rather than milk flow seems, from the available data, does depend, to some extent at least, upon carotene intake (Krauss, 1939).

Effect of vitamin A on antioxidant status of ewes: Malondialhyde is a good indicator of lipid peroxidation which can generally be used as a biomarker for radicalinduced damage and endogenous lipid peroxidation (Wang et al., 2008). In the present study, MDA concentration in the serum was reduced by inclusion of vitamin A in ewe diet. This decrease is likely attributed to the reduction of free radical production as it has been shown that vitamin A acted as a powerful free radical scavenger and was the most effective naturally occurring quencher of singlet oxygen and other free radicals (Whittaker et al., 1996; Dugas et al., 1999). The present findings are in agreement with the results on the antioxidant effects of vitamin A by Burton and Ingold (1984) and Kellog and Fridovich (1975) and consistent with the effect of vitamin A on enhancing the activities of GSH-Px in serum. The increased GSH-Px activities by vitamin A are likely due to the oxygen scavenging and peroxy radical quenching function of vitamin A (Stahl et al., 1997). The T-AOC concentration in the serum was also increased by supplemented vitamin A in this study. All these information indicated that both nonenzymatic and enzymatic antioxidant systems were enhanced by vitamin A supplementation at the level used in this study although it did not affect animal growth performance.

Effect of vitamin A on blood routine and metabolites of ewes: An increase in blood neutrophils is regarded as the first line of defense associated with clinical and subclinical infection (Vander Peet-Schwering et al., 2007). Lymphocytes were increased by the supplementation of vitamin A, indicating that vitamin A improved the immune function of lactating ewe in this study. Lin et al. (2002) suggested that vitamin A plays a role in modulating immune system and low vitamin A status has been reported to result in a reduction of cellmediated immune responses and decreased specific antibody responses following immunization (Bendich, 
1993). In this study, red blood cells, hemoglobin and haematocrit were also increased by supplementation of vitamin A. All these results suggest that supplementation of vitamin A in lactating ewe may have potential in enhancing immuno-system. The mechanism by which vitamin A modulates immunity is not clear, but may partly due to the antioxidant activity of vitamin A. It has been regarded that improving antioxidant status enhanced immune function of animals (Grimble, 2001). Bendich and Shapiro (1986) reported that supplementation rat with the vitamin A or $\beta$-carotene protected its immune responses to certain environmental sources of free radicals. Vitamin A can function as natural antioxidants to remove harmful free radicals produced through normal cellular activity and from environmental stressors, thereby maintaining the structural integrity of immune cells (Chew, 1996). The improved antioxidant status together with the enhanced immune function by supplementation of vitamin A observed in this study indicated that vitamin A may serve as an antioxidant to protect the immune cells against oxidant stressors and thereby maintain optimum immune function.

\section{CONCLUSION}

In conclusion, supplementation of vitamin $\mathrm{A}$ at the levels of 1000-5000 IU kg-1 DM to lactating Grey goat did not affect feed intake, milk yield and feed efficiency, but linearly and or quadratically enhanced serum antioxidant status of lactating Grey goat. Goat immune function was also improved by the supplementation of vitamin A this levels as indicated by the increase of red blood cells, lymphocyte and hemoglobine in blood of vitamin A supplementated Grey goat. Further studies are needed to elucidate the mechanism of immunoregulatory role of vitamin A.

\section{ACKNOWLEDGMENT}

The researchers gratefully acknowledge the technical assistance of staff of Animal Nutrition Research Institute, Shandong Agricultural University. We also thank Zhejiang Xinchang Pharmaceutical of China for providing the vitamin A preparations.

This study was supported by fund (2006BAD14B0703 ) of the Eleventh "Five-Year" Scientific and Technological Supported Projects of China.

\section{REFERENCES}

Alosilla, C.E. Jr., L.R. McDowell, N.S. Wilkinson, C.R. Staples and W.W. Thatcher et al., 2007. Bioavailability of vitamin A sources for cattle. J. Anim. Sci., 85: 1235-1238. PMID: 17178810
Arana, A., J.A. Mendizabal, M. Alzon, B. Soret and A. Purroy, 2008. The effect of vitamin A supplementation on postnatal adipose tissue development of lambs. J. Anim. Sci., 86: 3393-3400. PMID: 18676724

Arnett, A.M., M.E. Dikeman, C.W. Spaeth, B.J. Johnson and B. Hildabrand, 2007. Effects of vitamin A supplementation in young lambs on performance, serum lipid and longissimus muscle lipid composition. Am. J. Sci., 85: 3062-3071. PMID: 17785601

Barua, A.B. and J.A. Olson, 1998. Reversed-phase gradient high-performance liquid chomatagraphic procedure for simultaneous analysis of very polar to nonpolar retinoids, carotenoids and tocopherols in animal and plant sample. J. Chromatogr., 707: 69-79. PMID: 9613935

Bendich, A. and S.S. Shapiro, 1986. Effect of $\beta$ carotene and canthaxanthin on the immune responses of the rat. J. Nutr. 116: 2254. PMID: 3098935

Bendich, A., 1993. Physiological role of antioxidants in the immune system. J. Dairy Sci., 76: 2789-2794. PMID: 8227682

Benzie, I.F.F. and J.J. Strain, 1996. The Ferric Reducing Ability of Plasma (FRAP) as a measure of "antioxidant power", the FRAP assay. Anal. Biochem., 239: 70-76. PMID: 8660627

Bieri, J.G., T.J. Tolliver and G.L. Catignani, 1979. Simultaneous determination of $\alpha$-tocopherol and retinol in plasma or red cells by high pressure liquid chromatography. Am. J. Clin. Nutr., 32: 2143-2149. PMID: 484533

Bridges, C.D.B., 1984. Retinoids in Photosensitive Systems. In: The Ritinoids, Sporn, M.B., A.B. Roberts and D.S. Goodman (Eds.). Academic Press, New York, pp: 125-176. ISBN: 0781700825

Brody, T., 1993. Vitamins. Nutritional Biochemistry. Academic Press Inc., San Diego, pp: 403-410.

Burton, G.W. and K.U. Ingold, 1984. Beta-carotene: An unusual type of lipid antioxidant. Sci. Washington, DC., 224: 569-573. PMID: 6710156

Carrillo-Lopez, A., E. M. Yahia, G. K. Ramirez-Padilla, 2010. Bioconversion of Carotenoids in Five Fruits and Vegetables to Vitamin A Measured by Retinol Accumulation in Rat Livers. Am. J. of Agric. Biolol. Sci., 5: 215-221. DOI: 10.3844/ajabssp.2010.215.221.

Chew, B.P., 1996. Importance of antioxidant vitamins in immunity and health in animals. Anim. Feed Sci. Tech., 59: 103-114. Pll: 0377-8401(95)00891-8

Colby, R.W., T.J. Cunha and E.J. Warwick, 1950. Effect of vitamin A supplementation on reproduction of ewes grazed on green and dry summer ranges. J. Anim. Sci., 9: 446-456. PMID: 15436361 
Dallak, M., 2009. Camel's Milk Protects Against Cadmium Chloride-Induced Hypocromic Microcytic Anemia and Oxidative Stress in Red Blood Cells of White Albino Rats. Am. J. of Pharmacol. and Toxicol., 4: 136-143. DOI: 10.3844/ajptsp.2009.136.143.

Dennert, G., 1984. Retinoids and the Immune System: Immunostimulatin by Vitamin A. In: The Ritinoids, Sporn, M.B., A.B. Roberts and D.S. Goodman (Eds.). Academic Press, New York, pp: 372-390. ISBN: 0781700825

Dugas, T.R., D.W. Morel and E.H. Harrison, 1999. Dietary supplementation with $\beta$-carotene, but not with lycopene inhibits endothelial cell-mediated oxidation of low density lipoprotein. Free Radic. Biol. Med., 26: 1238-1244. PMID: 10381195

Grimble, R.F., 2001. Nutritional modulation of immune function. Proc. Nutr. Soc., 60: 389-397. DOI: 10.1079/PNS2001102

Hafemen, D.G., 1974. Effect of dietary selenium on erythrocyte and liver glutathione peroxidase in the rats. J. Nutr., 104: 580-587. PMID: 4823943

Kamiloglu, N.N., E. Beytut, A. Guven, C. Altinsaat, 2005. Changes in the erythrocyte anti-oxidant system of offspring of dams treated with vitamin A and $\beta$-carotene during gestation. Small Rumin. Res., 65: 142-148. DOI: 10.1016/j.smallrumres.2005.06001

Kellog, E.W. and I. Fridovich, 1975. Superoxide, hydrogen peroxide and singlet oxygen in lipid peroxidation by a xanthine oxidase system. J. Biol. Chem., 250: 8812-8817. PMID: 171266

Krauss, W.E., 1939. Recent advanced in vitamin nutrition. J. Anim. Sci., 1939: 425-435. http://jas.fass.org/cgi/content/abstract/1939/1/425

Lin, H., L.F. Wang, J.L. Song, Y.M. Xie and Q.M. Yang, 2002. Effect of dietary supplemental levels of vitamin A on the egg production and immune responses of heat-stressed laying hens. Poul. Sci., 81: 458-465. PMID: 11989744

Meacham, T.N., K.P. Bovard, B.M. Priode and J.P. Fontenot, 1970. Effect of supplemental vitamin A on the performance of beef cows and their calves. J. Anim. Sci., 31: 428-433. PMID: 5433459

Myers, G.S. Jr., H.D. Eaton and J.E. Jr. Rousseau, 1959. Relative value of carotene from alfalfa and vitamin A from a dry carrier fed to lambs and pigs. J. Anim. Sci., $\quad$ 18: 288-297. http://jas.fass.org/cgi/content/abstract/18/1/288

Oka, A., Y. Maruo, T. Miki, T. Yamasaki and T. Saito, 1998. Influence of vitamin A on the quality of beef from the Tajima strain of Japanese Black cattle. Meat Sci., 48: 159-167. DOI: 10.1016/S03091740(97)00086-7
Oyanagui, Y., 1984. Reevaluation of assay methods and establishment of kit for superoxide dismutase activity. Anal. Biochem., 142. PMID: 6099057

Pope, A.L., P.H. Phillips and G. Bohstedt, 1949. Vitamin $\mathrm{A}$ and $\mathrm{C}$ concentrations in the blood plasma of ewes, their milk and in the blood plasma of their lambs. J. Anim. Sci., 8: 57-66. http://jas.fass.org/cgi/reprint/8/1/57

Ray, B.C.S., 1948. Effect of season, breed and species of ruminants on the vitamin A potency of butterfat. J. Dairy Sci., 3: 165-172. DOI: 10.3168/jds.S00220302(48)92191-2

Roberts, A.B. and M.B. Sporn, 1984. Cellular Biology and Biochemistry of the Retinoids. In: The Ritinoids, Sporn, M.B., A.B. Roberts and D.S. Goodman (Eds.). Academic Press, New York, pp: 209-286. ISBN: 0781700825

Rode, L.M., T.A. McAllister and K.J. Cheng, 1990. Microbial degradation of vitamin $\mathrm{A}$ in rumen fluid of steers fed concentration, hay, or straw diets. Can. J. Anim. Sci., 70: 227-233. DOI: 10.3168/jds.S0022-0302(95)76808-4

SAS, 2000. Users Guide. Release 8.1 ed. SAS Institute Inc., Cary, NC.

Satake, D., H. Ebi, N. Oku, K. Matsuda and H. Takao et al., 2002. A sensor of blood cell counter using MEMS technology. Sens. Actuat., 83: 77-81. DOI: 10.1016/S0925-4005(01)01045-0

Smith, S.M., N.S. Levy and C.E. Hayes, 1987. Impaired immunity in vitamin A-deficient mice. J. Nutr., 117: 857-865. PMID: 3495650

Stahl, W., S. Nicolai, K. Briviba, M. Hanusch and G. Broszeit et al., 1997. Biological activities of natural and synthetic carotenoids: Induction of gap junctional communication and singlet oxygen quenching. Carcin, 18: 89-92. PMID: 9054593

Swanson, E.W., G.G. Martin, F.E. Pardue and G.M. Gorman, 1986. Milk production of cows fed diets deficient in vitamin A. J. Anim. Sci., 27: 541-548. http://jas.fass.org/cgi/content/abstract/27/2/541

Vander Peet-Schwering, C.M.C., A.J.M. Jansman, H. Smidt and I. Yoon, 2007. Effects of yeast culture on performance, gut integrity and blood cell composition of weanling pigs. J. Anim. Sci., 85: 3099-3109. PMID: 17609465

Wald, G., 1968. The molecular basis of visual excitation. Nature (Lond.), 219: 800-807. DOI: 10.1101/SQB.1988.053.01.035

Wang, Y.Z., C.L. Xu, Z.H. An, J.X. Liu and J. Feng, 2008. Effect of dietary bovine lactoferrin on performance and antioxidant status of piglets. Anim. Feed Sci. Technol., 140: 326-336. DOI: 10.1016/j.anifeedsci.2007.02.006 
Whittaker, P., W.G. Wamar, R.F. Chanderbhan and V.C. Dunkel, 1996. Effects of alpha-tocopherol and $\beta$ carotene on hepatic lipid peroxidation and blood lipids in rats with dietary iron overload. Nutr. Cancer 25: 119-128. PMID: 8710681
Zhang, G.F., Z.B. Yang, Y. Wang, W.R. Yang and S.Z. Jiang et al., 2009. Effects of ginger root (Zingiber officinale) processed to different particle sizes on growth performance, antioxidant status and serum metabolites of broiler chickens. Poul. Sci., 88: 2159-2166. PMID: 19762870 